\title{
Isotopic and sedimentological clues to productivity change in Late Riphean Sea: A case study from two intracratonic basins of India
}

\author{
P P Chakraborty ${ }^{1}$, A Sarkar ${ }^{2}, \mathrm{~S}$ K Bhattacharya ${ }^{3}$ and P Sanyal ${ }^{3}$ \\ ${ }^{1}$ Department of Applied Geology, Indian School of Mines, Dhanbad 826004 , India. \\ ${ }^{2}$ Department of Geology and Geophysics, Indian Institute of Technology, Kharagpur 721 302, India. \\ ${ }^{3}$ Physical Research Laboratory, Ahmedabad 380 009, India.
}

\begin{abstract}
Enriched ${ }^{13} \mathrm{C} /{ }^{12} \mathrm{C}$ ratios with $\delta^{13} \mathrm{C} \sim 3 \%$ (w.r.t PDB) of two Late Riphean ( 700-610 Ma) intracratonic carbonate successions viz., Bhander Limestone of Vindhyan Basin and Raipur Limestone of Chattisgarh Basin suggest higher organic productivity during this period. This view is supported by sedimentological evidence of higher biohermal growth and consequent increase in depositional relief in the low gradient ramp settings inferred for these basins. Oxygen isotope analysis of these carbonates show distinct segregation between enriched deeper water carbonate mudstone and depleted shallow water stromatolite facies that received fresh water influx. This shows that facies-specific analyses can be useful in understanding the depositional setting of these sediments.
\end{abstract}

\section{Introduction}

The Neoproterozoic period $(\sim 1000-545 \mathrm{Ma})$ is characterised by highly positive carbon isotope ratios with average $\delta^{13} \mathrm{C} \sim 4-5 \%$ and intermittent negative excursions (Kaufman and Knoll 1995 and references therein). The enriched $\delta^{13} \mathrm{C}$ pattern is explained in terms of high rate of organic matter burial, but the opinions vary regarding the causative mechanism for this increased burial. Enriched $\delta^{13} \mathrm{C}$ values during the Vendian $(\sim 590-550 \mathrm{Ma}$, associated with the Precambrian/Cambrian (Pc/C) boundary) are explained by increased burial due to higher sedimentation caused by enhanced continental erosion (Knoll et al 1986; Burns and Matter 1993; Corsetti and Hagadorn 2000; Santos et al 2000) whereas the enriched values during the upper Riphean $(\sim 730-620 \mathrm{Ma})$ are related to large scale anoxia through volcanic/hydrothermal input (Kaufman and Knoll 1995). ${ }^{87} \mathrm{Sr} /{ }^{86} \mathrm{Sr}$ ratio of marine carbonates in the sediments of the corresponding periods are $\geq 0.709$ and $\approx 0.706$ respectively corroborating the above views (Kaufman et al 1992). Knoll (1991) suggested increased oceanic productivity (extracting relatively more ${ }^{12} \mathrm{C}$ compared to ${ }^{13} \mathrm{C}$ from the oceanic reservoir), for the enriched $\delta^{13} \mathrm{C}$ values associated with $\mathrm{Pc} / \mathrm{C}$ boundary. It is not known whether this mechanism applies to the enriched values of older Riphean time as well. Although sedimentological evidences are useful to test higher productivity, most of the studies used stable isotope tracers as stratigraphic markers and to study changes in carbon reservoir during the Meso- and Neoproterozoic interval. Only a few studies have addressed the sedimentary environment-isotope connectivity (Misi and Veizer 1998).

Here we report combined isotopic and sedimentological evidences of higher Neoproterozoic oceanic productivity for two upper Riphean carbonate successions of Chattisgarh (Raipur Limestone) and Vindhyan (Bhander Limestone) Supergroups of central India. Detail facies analysis of the Bhander Limestone (Sarkar et al 1996) provided the basis for facies-specific isotope studies.

Keywords. $\delta^{13} \mathrm{C}$; Late Riphean; intracratonic; organic productivity. 
Facies and isotope analyses for the Raipur Limestone Formation are the outcome of the present study.

\section{Geology}

Vindhyan and Chattisgarh are two extensive Purana basins in peninsular India containing the Meso and Neoproterozoic sediments (Radhakrishna 1987; Banerjee and Majumder 1999; figure 1). The basins are similar in their mixed siliciclastic-carbonate lithology, absence of metamorphic overprinting and very low tectonic disturbance. Intracratonic sag model has been favoured for both (Das et al 1992; Bhattacharya 1996). Palaeocurrent and facies distribution data of the Vindhyans suggest a restricted connection with open sea towards NW (Chanda and Bhattacharya 1982) but no conclusive evidence is available for the opening of Chattisgarh Basin. Instead, a bull's-eye lacustrine model was proposed for Chattisgarh sedimentation (Das et al 1992). These basins do not contain signatures of Varanger glaciation, which is common in most of the Neoproterozoic successions elsewhere. Two carbonate formations viz., Raipur Limestone (RL) and Bhander Limestone (BL), which form parts of upper sedimentary successions of Chattisgarh Basin and Vindhyan Basin respectively (figure 1) constitute the materials for the present study.

Both Raipur Limestone and Bhander Limestone suffer from lack of radiometric age data specific to these formations. Age connotations of these carbonate units are based on stromatolite biostratigraphy or dates available for the adjacent geological formations. A lower bound for the age of Raipur Limestone can be estimated from K-Ar date ( 700-750 Ma; Kreuzer et al 1977) of authigenic glauconite minerals of an older stratigraphic horizon namely, sandstones of Chandarpur Group. Deb and Chaudhuri (2002) also regarded this age as the minimum age of sedimentation in Chattisgarh Basin. From studies of algal stromatolite assemblages in different formations of Chattisgarh Supergroup Chatterjee et al (1990) suggested middle to upper Riphean age. Observation of Linella-Gymnosolen-Baicalia stromatolite assemblage within Raipur Limestone prompted Moitra (1995) to suggest uppermost Proterozoic age.

Similarly, in Vindhyan succession most of the radiometric dates available are from Semri and Kaimur Formation, which are at lower stratigraphic level than Bhander Limestone. Soni et al (1987) summarised these dates provided by earlier workers (Vinogradov et al 1964; Crawford and Compston 1970 and many others) and suggested a depositional age between $1400 \mathrm{Ma}$ and
900 Ma for Semri and Kaimur Formation. Paul et al (1975) provided radiometric age of $974 \pm 30 \mathrm{Ma}$ to $1120 \pm 45 \mathrm{Ma}$ (K-Ar method) for kimberlite pipes of Majhgaon area, which crosscut Rewa sediments. These data suggest a depositional age for Bhander Limestone less than 900 Ma. Venkatachala et al (1996) from stromatolite biostratigraphy and microbial evidence derived Riphean age for Bhander Limestone. Based on oxygen, carbon and strontium isotope studies Kumar et al (2002) put a 700-540 Ma age bracket for the entire Bhander Group.

Various workers (Friedman and Chakraborty 1997; Banerjee and Majumder 1999) speculated continuation of both Raipur and Bhander Limestone across the $\mathrm{Pc} / \mathrm{C}$ boundary. Absence of tillites of Varanger glaciation (610-590 Ma) and metazoan assemblage of Cambrian affinity in these basins, however, rule out that these formations transgressed the $\mathrm{Pc} / \mathrm{C}$ boundary. Within this broad age framework provided by available radiometric age data, consideration of stromatolite biostratigraphy and $\mathrm{Sr}$ isotope results together with relative stratigraphic positions of these units (for example Bhander Limestone occurring towards lower part of the Bhander Group, figure 1) prompted us to assign upper Riphean age lying within 700 to $610 \mathrm{Ma}$ for both of these carbonate formations.

In general, omnipresent wave signature, consistent palaeoslope direction and parallel facies belts indicate homoclinal ramp geometry for deposition of these carbonate successions (Prasad and Varma 1991; Moitra 1995). Bhander Limestone of Vindhyan Basin is considered to be of marginal marine origin (Banerjee 1974; Chanda and Bhattacharya 1982; Prasad and Varma 1991). Sarkar et al (1996) identified five distinctive facies of wide palaeogeographic significance, ranging between beach shore face to distal shelf. These include Stromatolite (SM), Plane laminated mudstone (PLM), Planar and cross-stratified calc-arenite (PCS), Heterolithic limestone-shale (HL) and shale (SH; table 1). In the absence of any laterally traceable marker horizon in Bhander Limestone, a number of short sections exposed along roads and nala cuttings all along the belt reveal broad tabular geometry for most of these facies except for the SM and PCS facies. Reconstruction of lateral facies relationships revealed significant variation in the relief of SM facies (Sarkar et al 1996). The wedge shaped PCS facies that erosionally overlies deepwater stromatolite facies was interpreted as a product of lower sea level setting (Chakraborty 1996). A broad marine subtidal to intertidal palaeogeography has long been invoked for the dominantly stromatolitic succession of Raipur Limestone (Murti 1987; Moitra 1995). Detailed facies analysis also recognizes oscillation of this carbonate platform 


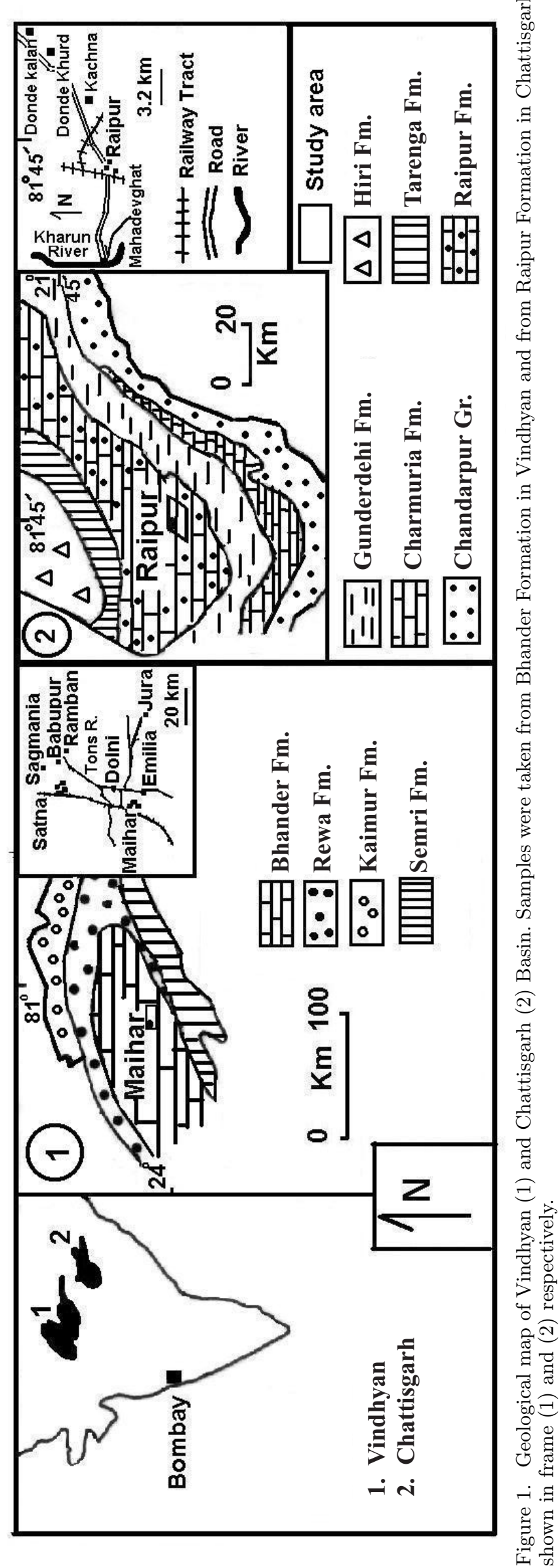




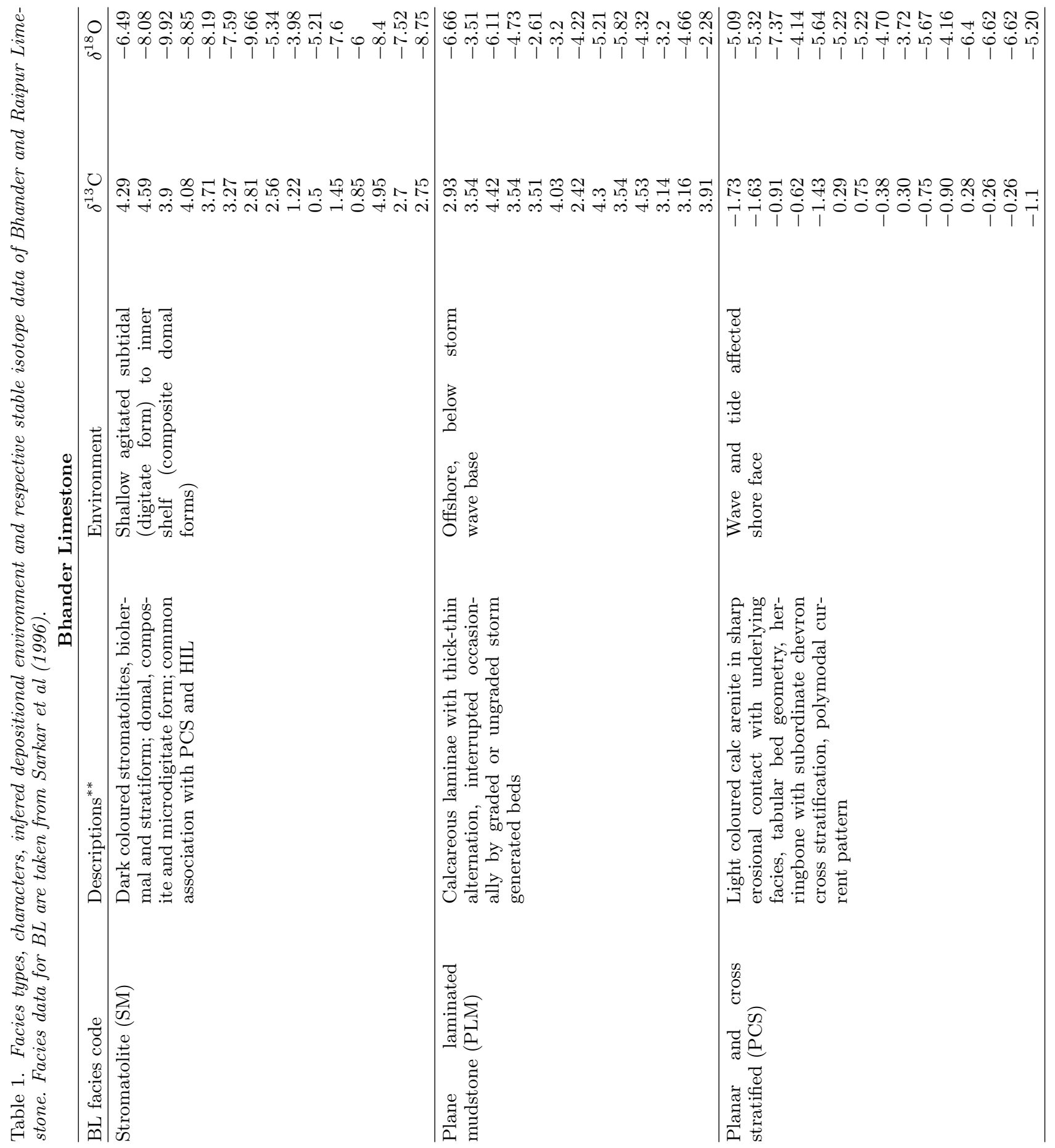




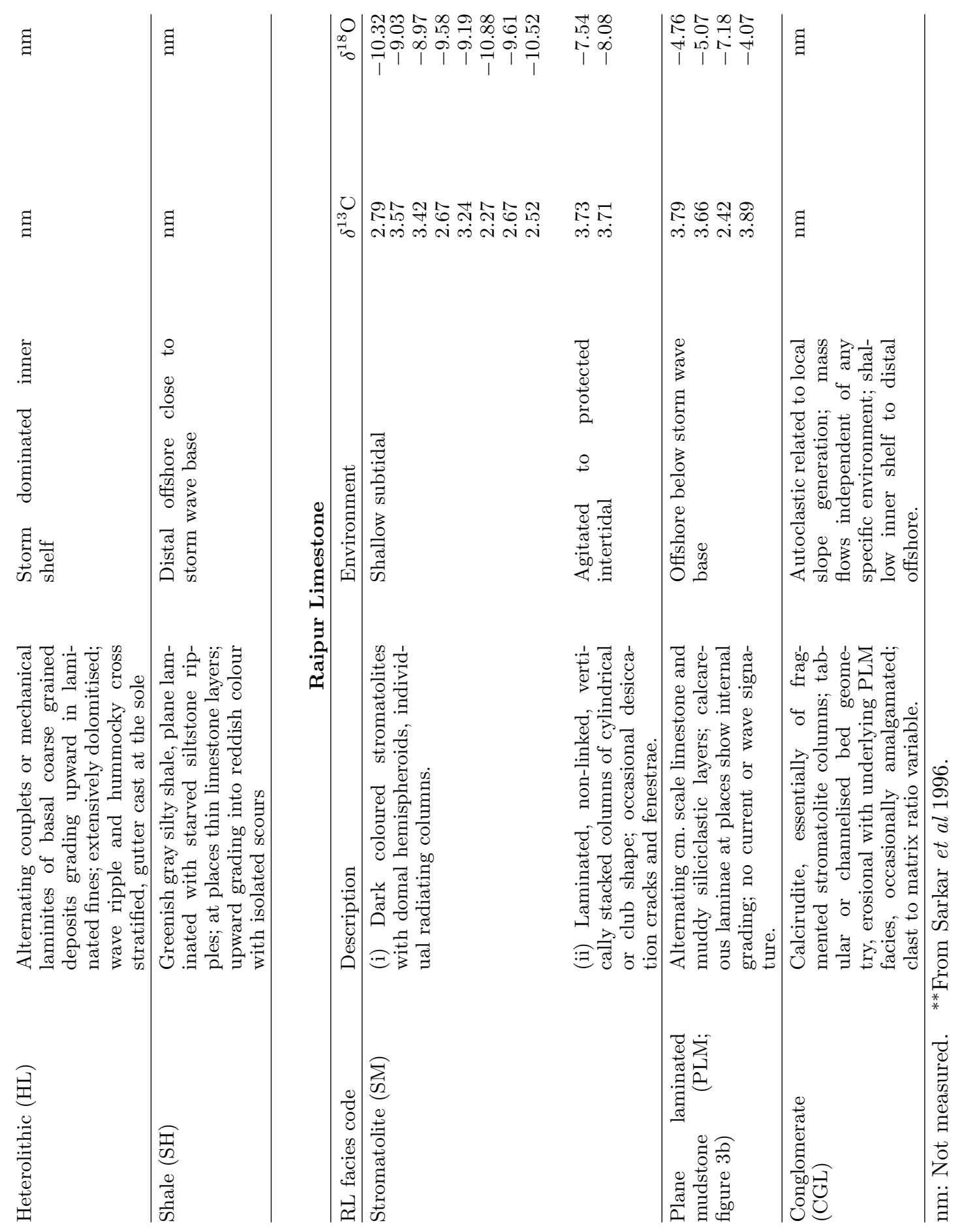




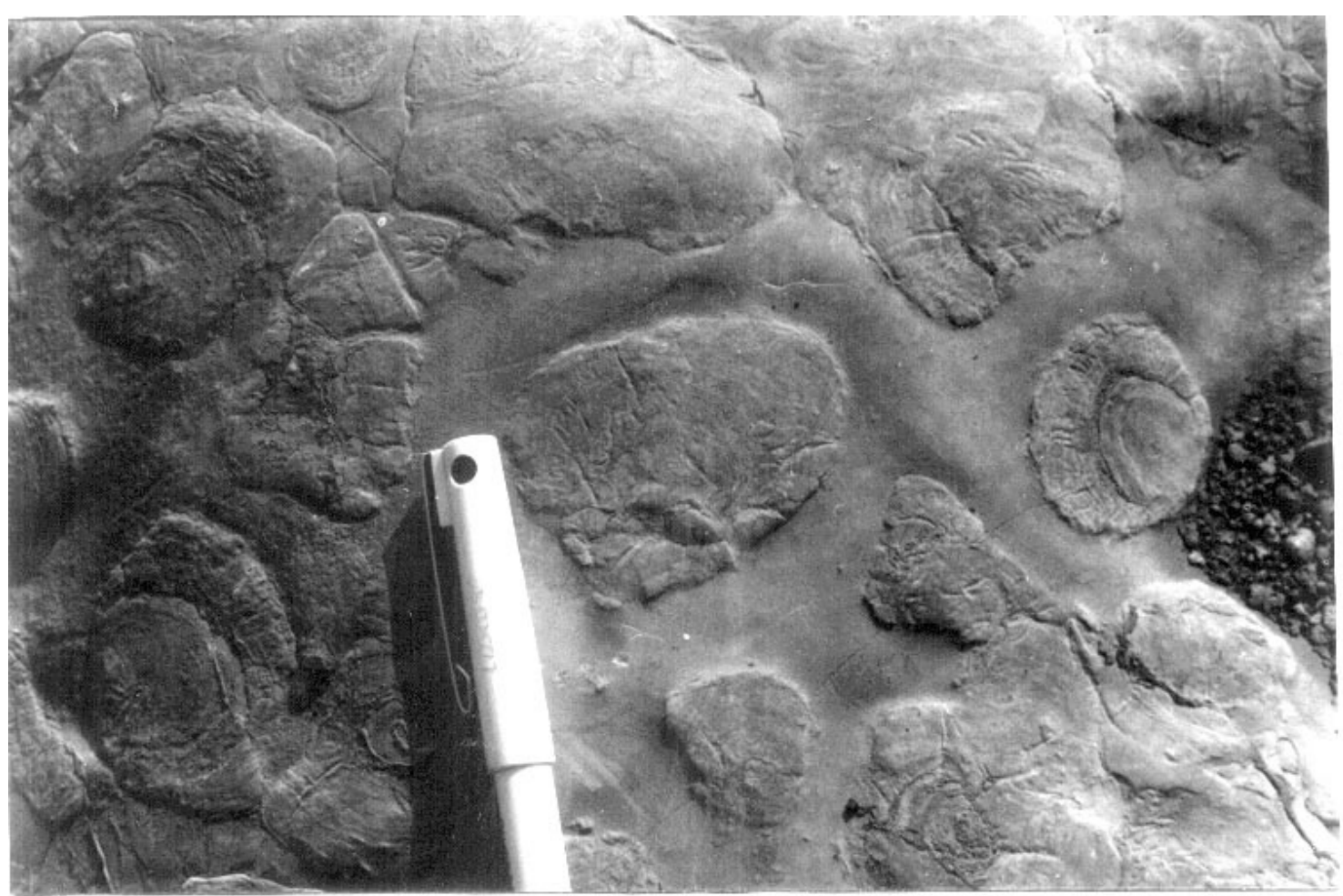

Figure 2. Bedding plane exposure showing concentric tapering (dessication) cracks on isolated stromatolite columns, Pikridih, Raipur Limestone, Chattisgarh; note high amount of inter columnar material.

between high and low depositional energy (discussed below).

\section{Results}

Detailed facies analyses of BL have been presented earlier by Sarkar et al (1996); here we report some relevant sedimentological aspects of RL. Stromatolites in the Raipur Limestone show columnar, domal and stratiform morphology. Character and volume of inter-columnar material, disposition of columns with respect to bedding plane and influx of siliciclastic detritus vary from place to place. Emergent features like desiccation cracks on solitary columns with high granular intercolumnar material (figure 2) at some discrete levels of stromatolite succession and plane laminated lime mudstone (figure 3) without any signature of wave or current action are also identified. A thick $(\sim 35 \mathrm{~m})$ intrabasinal autoclastic conglomerate within the $\mathrm{RL}$ is exclusively composed of stromatolite clasts (figure 4). Although dominantly of bedded geometry, these conglomerates, at places, preserve a channelised form that erosionally overlies the plane laminated lime mudstone.

Carbon $\left(\delta^{13} \mathrm{C}\right)$ and oxygen $\left(\delta^{18} \mathrm{O}\right)$ isotope analyses have been carried out on facies-specific carbonate samples (15 and 13 number of samples from SM and PLM facies of BL; 10 and 4 number of samples from SM and PLM facies of RL; table 1) follow- ing the procedure of Sarkar et al (1996). Analytical results are given in $d$-notation expressed w.r.t PDB with reproducibility of $\pm 0.1 \% \circ$ and $\pm 0.2 \%$ o for carbon and oxygen isotope ratios respectively. Alteration of original isotopic signatures due to diagenesis is minimum because none of these carbonate successions suffered deep burial diagenesis (Chanda et al 1977; Banerjee and Majumder 1999). Dominant micritic character of limestones, well preserved primary features including stromatolite laminae, pelloidal and intraclastic texture in lime mudstone (Burns and Matter 1993), poor correlation between $\delta^{13} \mathrm{C}$ and $\delta^{18} \mathrm{O}$ (figure 5 ) and persistent facies independent $\delta^{13} \mathrm{C}$ values (excepting the PCS facies; see later discussion) throughout the succession in both the formations supply additional evidence regarding absence of any deep burial diagenesis.

Mean $\delta^{13} \mathrm{C}$ values of samples from stromatolite (SM) and plane-laminated mudstone (PLM) facies of Bhander and Raipur Limestone are shown in figure 6 . The $\delta^{13} \mathrm{C}$ values are all positive for both $\mathrm{RL}$ (2.27\%o to $3.89 \%$; mean $3.19 \%$ $\pm 0.6 \%$ o $n=14$ ) and BL $(0.5 \%$ o to $4.95 \%$; mean $3.32 \%$ o $\pm 1 \%, n=28)$. These values are similar to earlier reported values of $\delta^{13} \mathrm{C}$ for BL (2.6 to 5.7\% ; Friedman and Chakraborty 1997; Kumar et al 2002) and for RL (2.5 to 5\%o; Schidlowski et al 1975 ). The mean $\delta$ values of samples from both the formations are within the range of $\delta^{13} \mathrm{C}$ values of marine carbon- 


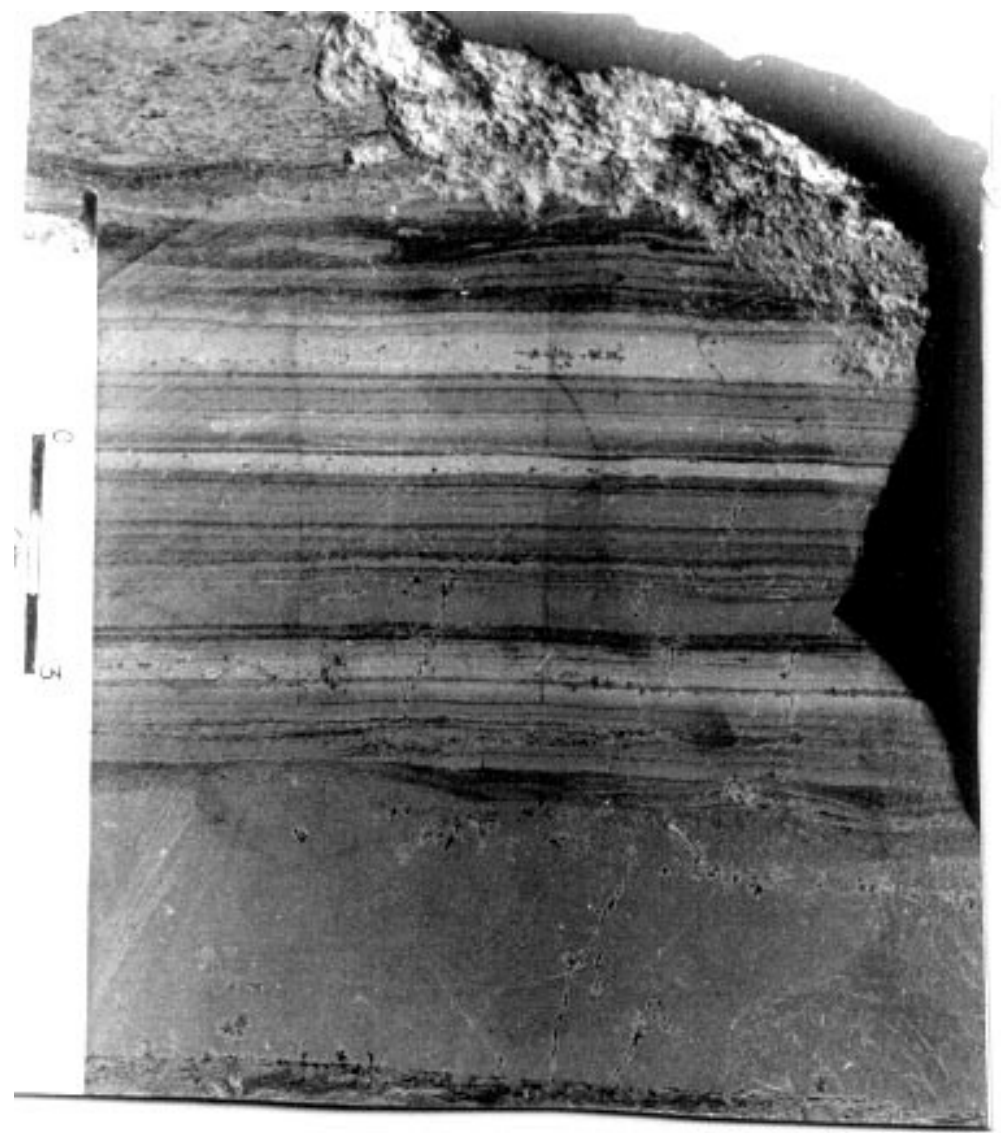

Figure 3. Plane laminated lime mudstone in Raipur Limestone, Kharun river, Raipur (see text).

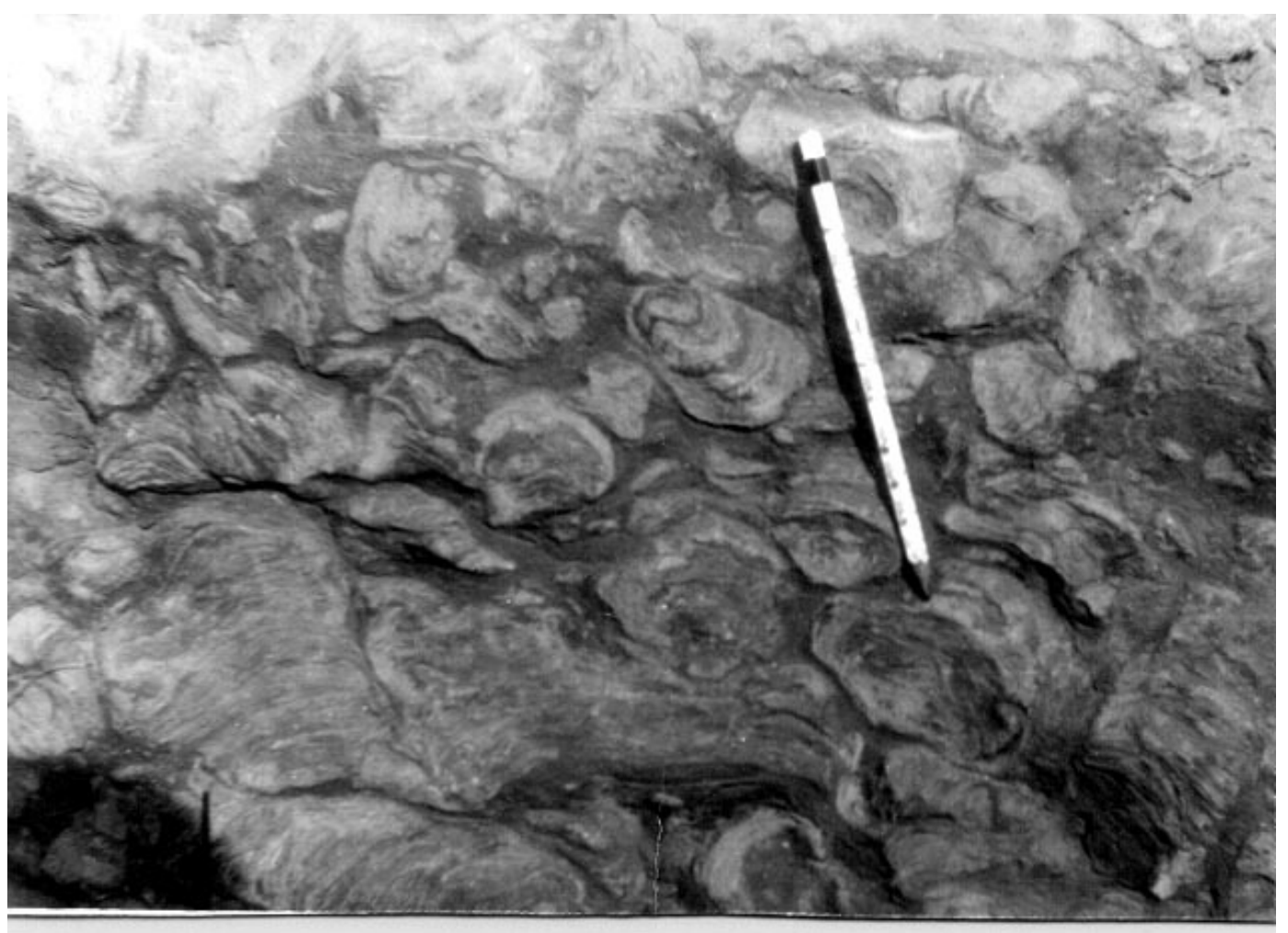

Figure 4. Bedding perpendicular section showing autoclastic conglomerate (with random stromatolitic clasts), Raipur Limestone, Kharun river section, Raipur. 

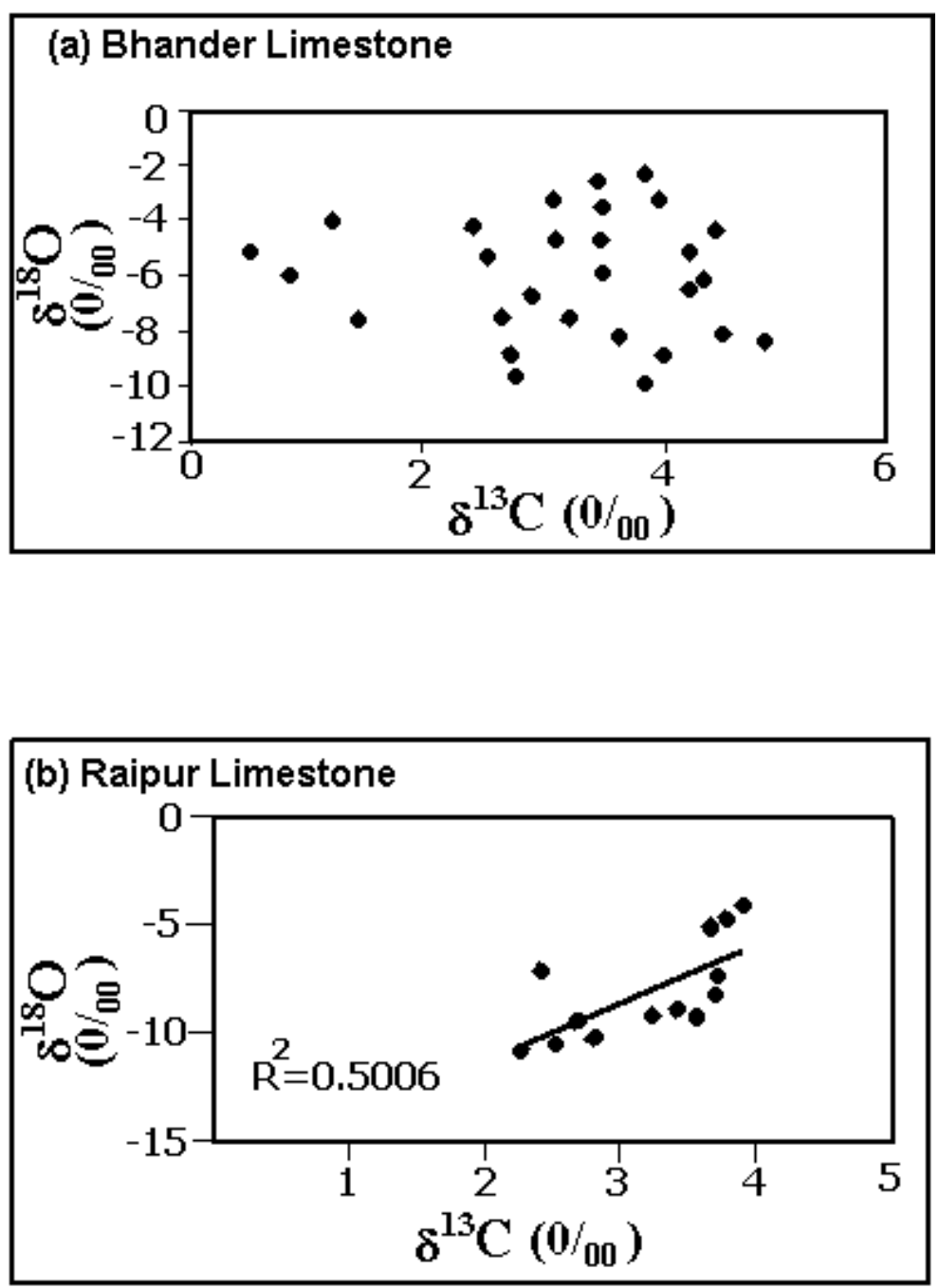

Figure 5. Plot of $\delta^{13} \mathrm{C}$ values against $\delta^{18} \mathrm{O}$ values for Bhander Limestone (a) and Raipur Limestone (b). Note poor correlation between the two in case of Bhander Limestone.
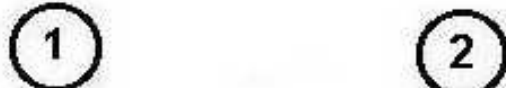

$$
\delta^{13} \mathrm{C}
$$
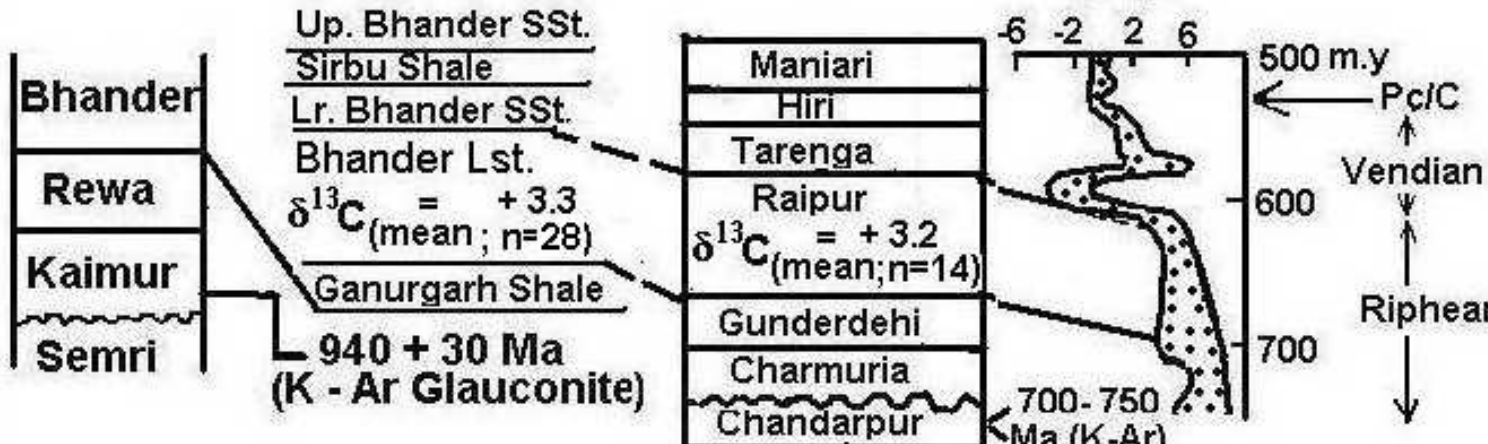

$-600$

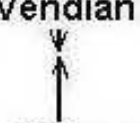

700

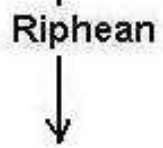

Figure 6. General stratigraphy for Vindhyan (1) and Chattisgarh (2) basin, inter-basinal correlation and average global $\delta^{13} \mathrm{C}$ curve for late Proterozoic time (after Kaufman et al 1992). 

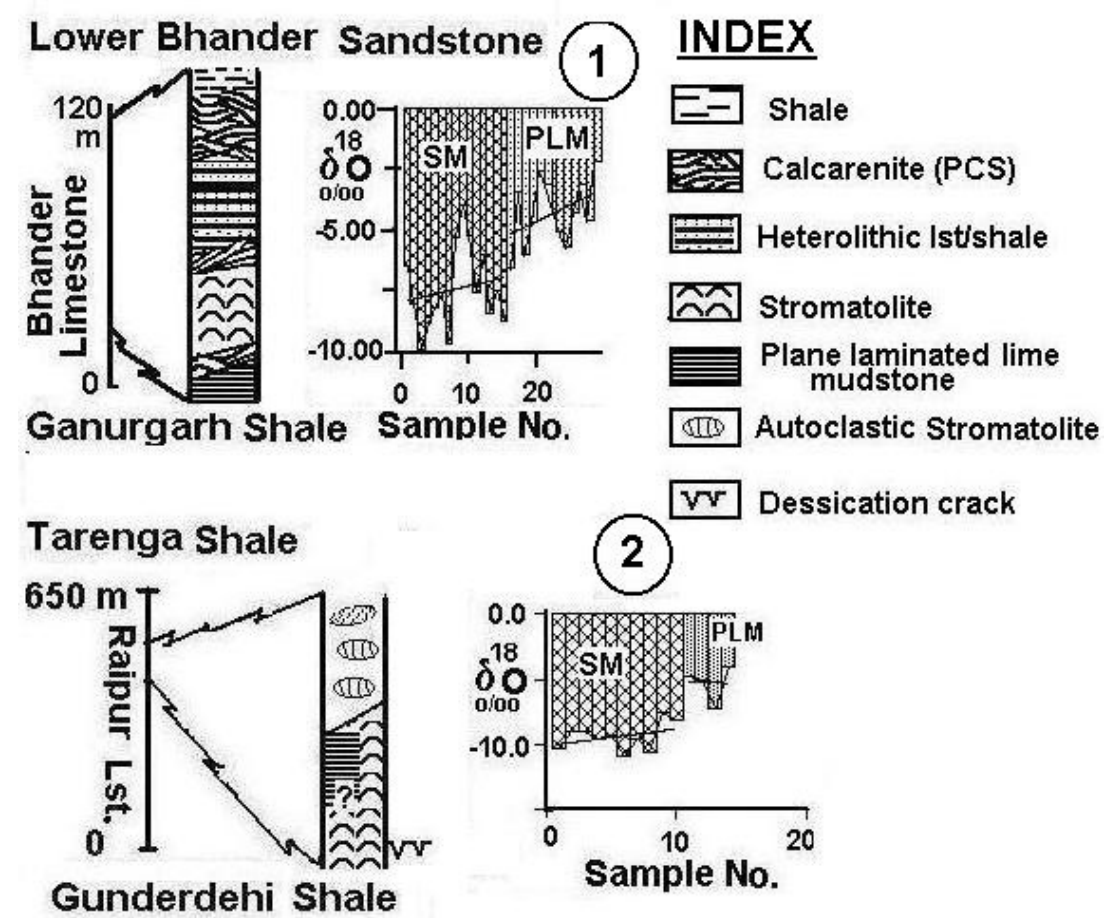

Figure 7. Representative lithologs for Vindhyan and Chattisgarh Basin. Difference in $\delta^{18} \mathrm{O}$ values between stromatolite and plane laminated mudstone facies in both the sections are shown by histograms alongside. Note distinct break in trendline between the two facies.

ates reported for the late Riphean period (3 to $6 \%$; Kaufman et al 1992; Kaufman and Knoll 1995; figure 6). Such enriched $\delta^{13} \mathrm{C}$ values from two widely separated basins (one land-locked and the other with restricted open ocean connection) may indicate a common forcing mechanism. In contrast to these general positive values of SM and PLM facies, $\delta^{13} \mathrm{C}$ value for 14 number of samples analysed from PCS facies of BL varies from $-1.73 \%$ o to $+0.28 \%$.

$\delta^{18} \mathrm{O}$ values of plane laminated lime mudstone and stromatolite facies vary significantly (figure 7 ). The plane laminated distal carbonate facies is enriched by $\sim 3-4 \%$ o compared to the shallower (shoreface) stromatolite facies. Stromatolitic limestone of RL, showing desiccation cracks, is enriched by $\sim 2 \%$ o $\left(\delta^{18} \mathrm{O}\right.$ value $\sim-7.5$ to $-8 \%$; table 1$)$ compared to the subtidal biohermal stromatolite colony $(\sim-9.8 \% \circ) \cdot \delta^{18} \mathrm{O}$ values from PCS facies of Bhander Limestone show a random variation from $-7.37 \%$ o to $-3.72 \%$ o without clustering in a restricted range.

\section{Discussions}

Stromatolite morphology is a useful tool for deciphering palaeo-water depth (cf. Glumac and Walker 2000). Variation of stromatolite morphology and the variation in character (sandy/muddy) and volume of inter-columnar material, column disposition etc. in Raipur Limestone suggest that this carbonate platform oscillated between high and low energy conditions. Emergent features like desiccation cracks with high granular intercolumnar material (figure 2) to distal plane laminated limemudstone (figure 3) suggest palaeogeographic variation from inner ramp (i.e., above fair weather wave base) to outer ramp (below storm wave base; cf. Burchette and Wright 1992). Occurrence of thick autoclastic conglomerate (figure 4) in this limestone sequence and the reported lowstand wedge of calc-arenite composition, encased within distal facies in BL (Chakraborty 1996) indicate generation of high accommodation space that is unlikely for an intracratonic platformal setting (Allen and Allen 1993). Bounding formations of Bhander Limestone (Ganurgarh shale and Lower Bhander sandstone) and Raipur Limestone (Gunderdehi shale and Tarenga shale; figure 1 and 6) contain dominant muddy lithology, indicative of general sediment starved depositional settings. Based on available age data and thickness of the units, Venkatachala et al (1996) estimated a low sedimentation rate $(\sim 70 \mathrm{~cm} / 1000$ years $)$ for the Vindhyan succession. This estimate does not consider the episodic nature of sedimentation history. Although no such estimate is available for the Chattisgarh Basin, the overall argillite-carbonate association of Raipur Group indicates a lower sedimentation rate. In the absence of signatures for syn-sedimentary tectonics (Chanda and Bhattacharya 1982; Murti 1987) or lack of any sig- 
nal for abrupt rise in relative sea level generation of such accommodation space in homoclinal ramp settings (lacking shelf-slope break) with slow rate of sedimentation can be accounted through rapid organic build-up and biohermal growth (Chakraborty 1996). Evidences for such biohermal growth both within Bhander Limestone and Raipur Limestone suggest high organic productivity in late Riphean time, irrespective of whether the depositional basin had open ocean connection (Vindhyan Basin) or not (Chattisgarh Basin). High $\delta^{13} \mathrm{C}$ signature of these carbonates is in conformity with this suggestion. Such high $\delta^{13} \mathrm{C}$ values $(\sim 1.5$ to $3.5 \%$ o $)$ are also recorded throughout the $200 \mathrm{~m}$ sequence of late Riphean carbonates from Bhima basin (Gopendra Kumar et al 1997).

In the absence of evaporitic condition, which may cause heavy carbon isotope enrichment (Knoll et al 1986) or increased reductant influx (and consequent anoxia; op. cit.; Kaufman and Knoll 1995) through coeval volcanic/hydrothermal activity, the uniformly enriched $\delta^{13} \mathrm{C}$ values in Bhander and Raipur Limestone Formations may indicate increased water column productivity since increased photosynthesis by rapid growth of algal community leads to enhanced $\delta^{13} \mathrm{C}$ of the $\Sigma \mathrm{CO}_{2}$ of the ambient oceanic reservoir. Lower $\delta^{13} \mathrm{C}$ values in some of the samples from SM facies of $\mathrm{BL}$ (in comparison to the earlier reported values) and in the PCS facies of BL, in general, could be due to precipitation in shallow coastal zone where both stromatolites and clastic carbonate particles form under the influence of continent derived $\Sigma \mathrm{CO}_{2}$ in the ambient water (Sarkar et al 1996).

Global average values of $\delta^{18} \mathrm{O}$ for late Precambrian carbonates range from $-10 \%$ (for limestones) to $-6 \%$ (for dolostones; Veizer and Hoefs 1976). High depositional temperature, isotopically depleted seawater or continuous isotopic exchange can explain such low values. Considering the $\mathrm{d} \delta^{18} \mathrm{O} / \mathrm{dt} \sim-0.25 \% /{ }^{\circ} \mathrm{C}$ (op. cit.), the $\delta^{18} \mathrm{O}$ difference of $\sim 3-4 \%$ o between the plane laminated facies (mean $\sim-5.7 \%$ o) and stromatolite facies (mean $-9.7 \%$ ) of Bhander and Raipur Limestone Formations require a spatial temperature variation of $\sim 16^{\circ} \mathrm{C}$. Such large intrabasinal ocean water temperature gradient between coeval supra- and subtidal zones is unlikely. The difference in $\delta$-values cannot be explained by any diagenetic process either since there is no marked mineralogical contrast between the above-mentioned facies or proof of variable burial suffered by them. The $\delta^{18} \mathrm{O}$ difference between these two facies thus probably reflects difference in $\delta^{18} \mathrm{O}$ composition of the ambient water within the same basin. Such a situation has been envisaged earlier for the Kutch basin, where mixing of ocean water with ${ }^{18} \mathrm{O}$-depleted freshwater in marginal environments like tidal flats, lagoons etc. are suggested for the observed shift of $\delta^{18} \mathrm{O}$ towards more negative values in the Kutch basin (Sarkar A et al 1996). The relatively enriched $\delta^{18} \mathrm{O}$ values of distal plane laminated facies of both the basins might indicate deep-water isotopic composition (Fairchild and Spiro 1987). Depleted $\delta^{18} \mathrm{O}$ values in the shallower stromatolite carbonates, on the other hand, suggest considerable influence of freshwater riverine influx. However, the $\delta^{18} \mathrm{O}$ of intertidal stromatolites with desiccation cracks are enriched $(\sim 2 \%$; table 1$)$ compared to the deeper subtidal ones. As dolomitisation in both these facies is insignificant, the enriched $\delta^{18} \mathrm{O}$ values may have resulted due to carbonate precipitation in an evaporative condition of protected (local sabkha?) intertidal nature. The $\delta^{18} \mathrm{O}$ values in the PCS facies of $\mathrm{BL}$ exhibit a large range $(-7.37$ to $-3.72 \%$ o) that is common for the cross-stratified clastic facies where carbonate particles are derived from various provenances. More $\delta^{18} \mathrm{O}$ analyses of faciesspecific samples are useful to decipher the depositional environment of the Proterozoic carbonate successions.

\section{Conclusions}

Stable isotope and sedimentological studies of late Riphean carbonate successions from the Proterozoic intracratonic Chattisgarh (Raipur Limestone) and Vindhyan (Bhander Limestone) basins of India indicate the following:

- Stromatolite and plane laminated lime mudstone facies of Raipur and Bhander Limestones show persistently enriched $\delta^{13} \mathrm{C}$ values $(\sim 3 \%)$. These data are interpreted in terms of high organic productivity during this period. The $\delta^{13} \mathrm{C}$ signature is independent of whether the basin had open ocean connection or not.

- Facies controlled $\delta^{18} \mathrm{O}$ analyses indicate that the deep-water carbonate facies are enriched by about $\sim 3-4 \%$ o compared to the shallow stromatolite facies. The latter one is probably more influenced by freshwater influx from the continent. Thus facies-specific oxygen isotope analysis may be useful in deciphering the environment of deposition of marine carbonates.

\section{Acknowledgements}

We thank Prof. P K Bose for stimulating discussions and Dr. S Mohanty for computer grafting. PPC acknowledges CSIR for financial support for Vindhyan work. Financial assistance from DST 
and ISM for carrying out the fieldwork in Chattisgarh basin is gratefully acknowledged. We also thank the Director, ISM for encouragement.

\section{References}

Allen P A and Allen J R 1993 Basin analyses, principles and applications. Blackwell Sci. pub., 451 pp.

Banerjee D M and Majumder A 1999 On the late Neoproterozoic-Early Cambrian transition events in parts of east Gondwanaland; Gond. Res. 2 199-211

Banerjee I 1974 Barrier coastline sedimentation model and the Vindhyan example. Golden Jub. Volume; Quart. Jour. Geol. Min. Met. Soc. India 81-101

Bhattacharya A 1996 (ed) Recent advances in Vindhyan geology; Mem. Geol. Soc. India. $36331 \mathrm{pp}$.

Burchette T P and Wright V P 1992 Carbonate ramp depositional systems; Sedimentary Geology 79 3-57

Burns S J and Matter A 1993 Carbon isotopic record of the latest Proterozoic from Oman; Ecologae geol. Helv. 86 595-607

Chakraborty P P 1996 Facies and sequence development in some late Proterozoic Formations in Son valley, India with some clues for basin evolution; Unpub. $\mathrm{Ph} \mathrm{D}$ thesis. Jadavpur University, Calcutta, India. 104 pp.

Chanda S K and Bhattacharya A 1982 Vindhyan sedimentation and palaeogeography: post Auden developments. In: Geology of Vindhyanchal, (eds) K S Valdiya, S B Bhatia and V K Gaur (Delhi: Hind. Pub. Corp.,) 88-101

Chanda S K, Bhattacharya A and Sarkar S 1977 Deformation of ooids by compaction in the Precambrian Bhander Limestone, India; Geol. Soc. Am. Bull. 88 $1577-1585$

Chatterjee (Jha) N, Das N, Ganguly (Das) M, Chatterjee B 1990 Stromatolite based biostratigraphic zonation of Chandi Formation, Raipur Group, in and around Dhamda-Nandini area, Durg district, Madhya Pradesh; Geol. Surv. India Spec. Publ. 28 400-410

Corsetti F A and Hagadorn J W 2000 PrecambrianCambrian transition: Death valley, United States; Geology, 28 299-302

Crawford A R and Crompston W 1970 The age of the Vindhyan system of peninsular India; Q. J. Geol. Soc. London 125 351-371

Das, D P, Kundu A, Das N, Dutta D R, Kumaran K Ramamurthy S, Thanavelu C and Rajaiya V 1992 Lithostratigraphy and sedimentation of Chattisgarh basin; India Min. 46 271-288

Deb S P and Chaudhuri A K 2002 Stratigraphic architecture of the Proterozoic succession in the eastern Chattisgarh basin, India: Tectonic implications; Sedimentary Geology $147105-125$

Fairchild I J and Spiro B 1987 Petrological and isotopic implications of some contrasting late Precambrian carbonates, NE Spittsbergen; Sedimentology 34 973-989

Friedman G M and Chakraborty C 1997 Stable isotopes in marine carbonates: Their implications for the palaeoenvironment with special reference to the Proterozoic Vindhyan carbonates (Central India); J. Geol. Soc. India 50 $131-159$

Glumac B and Walker K R 2000 Carbonate deposition and sequence stratigraphy of the terminal Cambrian Grand cycle in the southern Appalachians, USA; J. Sed. Res. 70 952-963

Gopendra Kumar, Ravi Sanker Maithy P K, Mathur V K, Bhattacharya S K and Jani R A 1997 Terminal Proterozoic-Cambrian sequences in India: A review with special reference to Precambrian-Cambrian boundary; Paleobotanist 46 19-31

Kaufman A J and Knoll A H 1995 Neoproterozoic variations in the C-isotopic composition of seawater: Stratigraphic and biogeochemical implications; Precamb. Res. 73 27-49

Kaufman A J, Knoll A H and Awramik S M 1992 Biostratigraphic and chemostratigraphic correlation of Neoproterozoic sedimentary successions: Upper Tindir Group, northwestern Canada, as a test case; Geology 20 181-185

Knoll A H 1991 End of the Proterozoic Eon; Scient. Amer. 265 64-73

Knoll A H, Hays J M, Kaufman A J, Swett K and Lambert I B 1986 Secular variation in carbon isotope ratios from upper Proterozoic successions of Svalbard and east Greenland; Nature 321 832-838

Kreuzer H, Karre W, Karsten M, Scnitzer W A, Murti K S and Srivastava N K 1977 K-Ar dates of two glauconites from the Chandrapur series (Chattisgarh/India): On the stratigraphic status of the late Precambrian basins in central India; Geol. Jb. 28 23-36

Kumar B, Das Sharma S, Sreenivas B, Dayal A M, Rao M N, Dubey N and Chawla B R 2002 Carbon, oxygen and strontium isotope geochemistry of Proterozoic carbonate rocks of the Vindhyan basin, central India; Precamb. Res. $11343-63$

Misi A and Veizer J 1998 Neo-Proterozoic carbonate sequence of the Una group, Irece basin: Chemostratigraphy, age and correlations; Precambrian Research 8987 100

Moitra A K 1995 Depositional environmental history of the Chattisgarh basin, M.P., based on stromatolites and microbiota; J. Geol. Soc. India 46 359-368

Murti K S 1987 Stratigraphy and sedimentation in Chattisgarh basin, In: Purana basins of peninsular India, (ed) B P Radhakrishna Mem. Geol. Soc. India, 6 239-261

Paul D K, Rex D C and Harries P G 1975 Chemical characteristics and K-Ar ages of Indian kimberlite; Bull. Geol. Soc. Am. 86 364-366

Prasad B and Varma K K 1991 Vindhyan basin: A review, In: Sedimentary basins of India (eds) S K Tandon, C C Pant and S M Casshyap 50-62

Radhakrishna B P (ed) 1987 Purana basins of peninsular India; Mem. Geol. Soc. India 6518 pp.

Santos R V, de Alvarenga C J S, Dardenne M A, Sial A N, Ferreira V P 2000 Carbon and oxygen isotope profiles across Meso-Neo-Proterozoic limestones from central Brazil: Bambui and Paranoa groups; Precambrian Research 104 107-122

Sarkar A, Ray A K and Bhattacharya S K 1996 Stable isotope studies of fossiliferous Palaeogene sequence of Kutch, Western India: palaeoenvironmental implications; Palaeogeography, Palaeoclimatology, Palaeoecology $12165-67$

Sarkar S, Chakrabarty P P and Bose P K 1996 Proterozoic Lakheri (Bhander) limestone, central India: Facies, Paleogeography and physiography, In: Recent advances in Vindhyan geology, (ed) A Bhattacharya Mem. Geol. Soc. India 36 5-26

Schidlowski M, Eichmann R and Junge C E 1975 Precambrian sedimentary carbonates: carbon and oxygen isotope geochemistry and implications for the terrestrial oxygen budget; Precamb. Res. 2 1-69

Soni M K, Chakraborty S and Jain V K 1987 Vindhyan Super Group - A review. In: Purana basins of peninsular India. (ed) B P Radhakrishna Geol. Soc. India Mem. 6 87-138

Veizer J and Hoefs J 1976 The nature of $\mathrm{O}^{18} / \mathrm{O}^{16}$ and $\mathrm{C}^{13} / \mathrm{C}^{12}$ secular trends in sedimentary carbonate rocks; Geochim. Cosmochim. Acta. 40 1387-1395 
Venkatachala B S, Sharma M and Shukla M 1996 Age and life of the Vindhyans-facts and conjectures, In: Recent advances in Vindhyan geology. (ed) A Bhattacharya, Mem. Geol. Soc. India. 36 137-166
Vinogradov A P, Tugarinov A I, Zhykov C I, Stapricova N I, Bibicova E V and Khorre K G 1964 Geochronology of the Indian Precambrian. $2^{\text {nd }}$ Int. Geol. Cong., Pt. 10 $553-567$

MS received 7 January 2002; revised 18 August 2002 